\title{
Garcinia cambogioides, the correct name for G. morella (Clusiaceae), its taxonomy, typification and notes on the status of $G$. pictoria
}

\author{
Shameer P.S. ${ }^{1} \&$ N. Mohanan ${ }^{1 \& 2^{*}}$ \\ 1Jawaharlal Nehru Tropical Botanic Garden and Research Institute, Palode, Thiruvananthapuram, Kerala - 695562 , India. \\ ${ }^{2}$ M S Swaminathan Research Foundation, Wayanad, Kerala - 673 577, India. \\ *E-mail: nmohanan59@gmail.com
}

\begin{abstract}
The priority of the name Garcinia cambogioides (Murray) Headland over G. morella (Gaertn.) Desr. is established. Further, G. pictoria Roxb. is reduced as a variety under G. cambogioides as var. pictoria (Roxb.) P.S.Shameer \& N.Mohanan. Typification of the name G. cambogioides is also done, in accordance with the latest nomenclature code.
\end{abstract}

Keywords: Clusiaceae, Garcinia, India, Taxonomy, Typification.

\section{Introduction}

The genus Garcinia L. (Clusiaceae), with c. 250 species of trees and shrubs, has a pantropical distribution with species richness in Southeast Asia, Indian subcontinent and Tropical Africa (Rogers \& Sweeney, 2007; Shameer et al., 2016). The genus is represented in India by 31 species and 5 varieties (Maheshwari, 1964; Shameer et al., 2016, 2017), distributed mainly in the three centres of diversity, Northeast India, the Western Ghats and Andaman and Nicobar Islands.

During the taxonomic studies on the genus Garcinia in India, we came across a nomenclatural ambiguity in the species G. morella (Gaertn.) Desr., which is resolved here. Taxonomic uncertainty has also been observed in Garcinia pictoria Roxb. While some authors (Wight, 1839; Choisy, 1851; Planchon \& Triana, 1860; Vesque, 1893) consider G. pictoria as

Received: 10.04.2020; Revised \& Accepted: 04.12.2020

Published Online: 31.12.2020 a distinct species, many others (Anderson, 1874; Dunn, 1915) consider it as synonymous to $G$. morella, and also elucidated the close relationship between both species.

\section{Nomenclature}

In all hitherto literature (Anderson, 1874; Dunn, 1915; Maheshwari, 1964; Saldanha \& Nicolson, 1976; Dassanayake \& Fosberg, 1980; Singh, 1993; Arisdason \& Daniel, 2005) and databases of plant names (The Plant List, World Flora Online), G. morella (Gaertn.) Desr. is treated as correct name of the taxon, and names such as G. cambogioides (Murray) Headland, G. gutta Wight, Stalagmitis cambogioides Murray, and Hebradendron cambogioides (Murray) Graham are treated as synonyms under G. morella.

On perusal of protologues of these names, we found that the combination G. cambogioides (Murray) Headland (1856) was based on the name Stalagmitis cambogioides Murray (1789), whereas G. morella (Gaertn.) Desr. (1792) was based on Mangostana morella Gaertn. (1790). After detailed studies and consultation with nomenclatural experts, we conclude that the priority of the epithet cambogioides starts from Stalagmitis cambogioides (Murray, 1789), whereas that of morella starts from Mangostana morella (Gaertner, 1790). Therefore, nomenclatural change is effected for the taxon as G. cambogioides Headland and the name G. morella is synonymised, since the former has priority over the latter as per the Code (Thurland et al., 2018). 


\section{Status of Garcinia pictoria}

Roxburgh (1832) described the species G. pictoria, based on a collection by Samuel Dyer from Wayanad district, Kerala. Wight (1839), Choisy (1851), Vesque (1893) and Planchon and Triana (1860) followed Roxburgh in recognising the species as a distinct one, whereas Anderson (1874) and Dunn (1915) considered it as synonymous to G. morella. Maheshwari (1964) treated it as a distinct species, with a note that "the species is closely allied to G. morella and scarcely distinguishable except by the female flowers". Singh (1993) also considered it distinct, but commented that "this species is closely allied to G. morella, under which it is sometimes sunk". Arisdason and Daniel (2005) followed Roxburgh and Maheshwari (1964) for inclusion of G. pictoria in their treatment. Headland (1856), who made the combination G. cambogioides had treated G. pictoria as a distinct species, with the help of illustrations of both species (Fig. 1).

During the present study, we collected specimens of G. pictoria from the type locality Wayanad and compared it with G. cambogioides (= G. morella). Except for the difference in number and structure of staminal mass, staminodes and stigmatic lobes (Fig. 2), both species are similar in all other

\section{0}

casbogla.

[Thalamigione.

G. (v. II.) pictoria (fig. 49) is a tall tree with a protty thick hark having considerah) masses of gamboge on its inside. Laves with short petioles, ablong ventricese, mether acute, frotn $s$ to 4 luches loug by lo or 2 brodi. Flowers yellow, axillary, solitary. Calyx (8) pernanent of 2 pairs of concave obluse septis Petals fokr. Stamens from 10 to is, with their flaments unitod into fnur bodies, which are again united at the basc lato a barnow ring. "Anthers of the male flower 'peltate, of the female ?. membranaocosas (1) scpals 4 persistent. Petals 4 . Stamens (:) monadcl(4) of 3 flat and umbilicate terminal lid. The inflerescenes of the female tree is similar to that of the male. Its flowers white and a litte larger. with a germen in miniature of the fruit, nnd sturnounded like it with soveral (ccu?) abortlve stamens; crowned by s lobed and murieated sessilc stipma. The berry (5) is may or 1 eelled, cells one acedod. Cotyledons flesby, unitod. Radicle centraJ, flifort. Trees with entive lesves.

Besides the above species, there is probably another belonging to the same sub-genus, or to the same group of a larger genus, i.e., Garcinia, which yields a very good kind of Gamboge, and one which may prove a good substitute for either the Ceylon or Siam kind,-and that is Gaseinic pietoria, Roxb. Fl. Ind. ii. p. 627 . Dr. Roxburgh says, "I have frequently received samples of the Gamboge the produce of this tree, from my good correspondent, Mr. S.

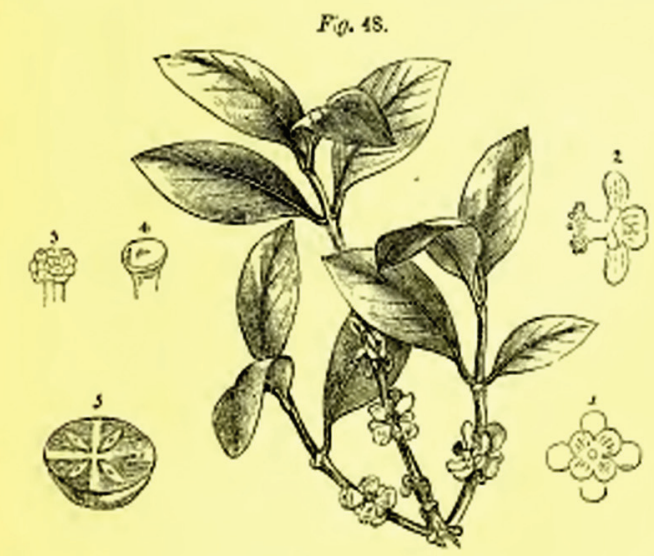

Dyer, the Surgeon at Tellicherry, and I have uniformly found it, even in its crude unrefined state, superior in colour, while recent, to every other kind I have yet tried; but not so permanent as that from Chima." This, Mir. Dyer, when in London, informed me he z 2

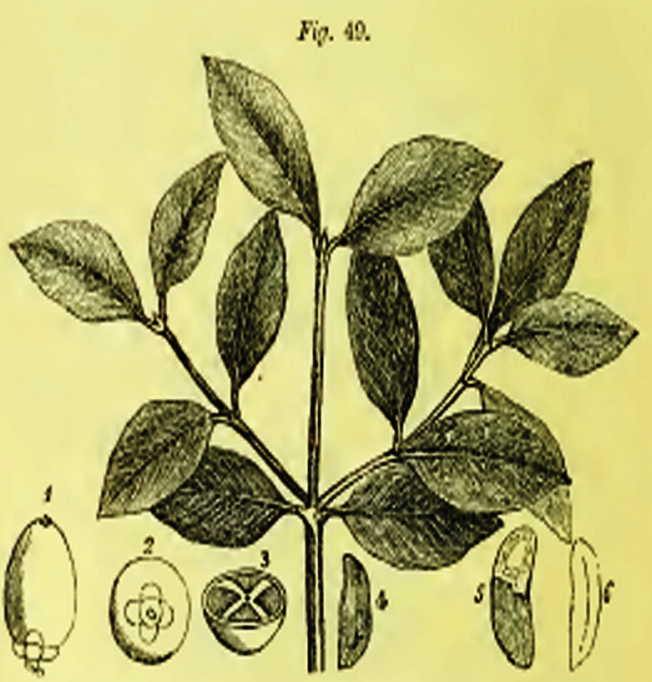

lobod and seemingly fertile" Germ superior, round, t-cellod, (3) one ovule in each attachod to the axis a little abore its tuiddle. Stigms 4-lobexi, permanent. Berry (1, 2, 3.) size of a large cherry, onal, smooth. very slightly narked with four lobes, enowner with the seasile, 4.lobed verrucose, permanebt stizms. Bind leathery, of a roddish colnur. Eceds 4 , when all ripen $(4,5,6)$ oblnag reniform. The filaments in the male flimwers are degeribed as being numerous and the anthers paltate, A native of the Malabar and Wyunad jungles, and the Mysore ghauts; slos found noar Mergui in Throy. (t, elliptint, a native of Silhet, has also been found in Tavoy, and yiclds a kind of Gamboge.

Dr. Wight, who has paud considerable attention to the chancters of the

Fig. 1. a. Protologue of Garcinia cambogioides (Murray) Headland; b. Garcinia pictoria Roxb. Reproduced with permission. 
characters such as habit, texture of bark, colour of exudate, size and shape of leaves, flowers, fruits and seeds. Considering these, G. pictoria is reduced as a variety under G. cambogioides, rather than merging with it.

\section{Taxonomy and typification}

Garcinia cambogioides (Murray) Headland, Man. Mater. Med. Therap. ed. 3: 339, f. 48. 1856. Stalagmitis cambogioides Murray, Commentat. Soc. Regiae Sci. Gott. 9: 173. 1789; G. Don, Gen. Syst. 1: 621. 1831. Lectotype (first-step designated by Maheshwari, 1964; second-step designated here): SRI LANKA, s.d., Hermann 195 (BM [BM000621661 digital image!]).

Garcinia morella (Gaertn.) Desr. in Lam., Encycl. 3: 701. 1792; T.Anderson in Hook.f., Fl. Brit. India 1: 204. 1874; Dunn in Gamble, Fl. Madras: 74. 1915; Maheshw., Bull. Bot. Surv. India 6: 135. 1964; N.P.Singh in B.D.Sharma \& Sanjappa, Fl. India 3: 119. 1993. Mangostana morella Gaertn., Fruct. Sem. P1. 2: 106, t. 101. 1790.

Hebradendron cambogioides (Murray) Graham, Compan. Bot. Mag. 2: 199, t. 27. 1836.

Garcinia gutta Wight, Ill. Ind. Bot. 1: 126. 1840.

Dioecious, evergreen trees, up to $18 \mathrm{~m}$ tall; bark brownish-grey or brown to dark brown, smooth; blaze deep yellow; exudation deep yellow or orange-yellow, sticky; branches spreading with pendulous tips; branchlets quadrangular, glabrous. Leaves opposite, elliptic, ovate or obovate, 10-15 $\times 4-8 \mathrm{~cm}$, acute or cuneate at base, revolute and wavy at margins, obtuse to shortly obtuseacuminate at apex, coriaceous, glabrous; midrib raised on both sides, more conspicuous below; lateral veins 8-12 pairs on either side of midrib, inconspicuous; exudate canals inconspicuous on both surfaces; petioles $8-10 \mathrm{~mm}$, with longitudinal ridges, glabrous, adaxially ligulate at the base. Male flowers tetramerous, axillary or on axils of fallen leaves, fascicled, c. 3-flowered, 1-1.2 × 5-10 mm, sessile or shortly pedicelled (4-6 mm), stout; sepals free, orbicular or elliptic, convex, 4-6 × 2-4 mm (inner pair comparatively larger), coriaceous; petals free, white to pink, suborbicular, 5-8 × 4-6 mm, membranous, glabrous; stamens c. 25, in a central tetragonous mass; filaments short, obconic, free at apex; anthers red, orbicular, flattened, peltate, plurilocular, dehiscence circumscissile or transverse; rudimentary pistil absent. Female flowers tetramerous, axillary, solitary, c. $1 \times 0.5 \mathrm{~mm}$, sessile; sepals free, orbicular, convex, c. $5 \mathrm{~mm}$, all equal, coriaceous, glabrous, margins membraneous; petals free, ovate, 5-6 × 3-5 mm, glabrous, pink; staminodes $12-14$, fascicled, each fascicle with 3-5 staminodes and arranged in a ring round the ovary; filaments slender, split, glabrous; ovary subglobose, glabrous, 4-locular; stigma peltate, serrately manylobed, coronate, tubercled, persistent. Berries subglobose, rarely globose, $2.5-3 \times 2-3 \mathrm{~cm}$, smooth, yellow with reddish tinge, contains much yellow resins, crowned by 4, round, confluent papillate stigma. Seeds 3 or 4, ovoid-reniform, c. $1.5 \mathrm{~cm}$ long, laterally compressed, muricate, dark brown.

\section{Key to the varieties}

1. Stamens c. 25, in a tetragonous mass; staminodes 12-14; filaments connate into 3-5 bundles round the ovary; stigma serrately many-lobed .......................... var. cambogioides

1. Stamens 35-40, in a subglobose mass; staminodes c. 20; filaments connate into an entire sheath round the ovary; stigma roughly 4-lobed. var. pictoria

Garcinia cambogioides (Murray) Headland var. cambogioides

Fig. 3

Flowering \& fruiting: Flowering from November to December; fruiting from July to August.

Habitat: Evergreen and semi-evergreen forests, up to $1100 \mathrm{~m}$, commonly found on stream sides.

Distribution: Sri Lanka, Bangladesh and India.

Specimens examined: INDIA, Arunachal Pradesh, East Siang district, Pasighat, 05.03.1912, I.H. Burkill 36754 (CAL). Karnataka, Chikkamagaluru district, Kemmengunda, 1425 m, 01.12.1983, K.V. Asha 1299 (CALI); Saingeri, 850 m, 09.11.1983, 

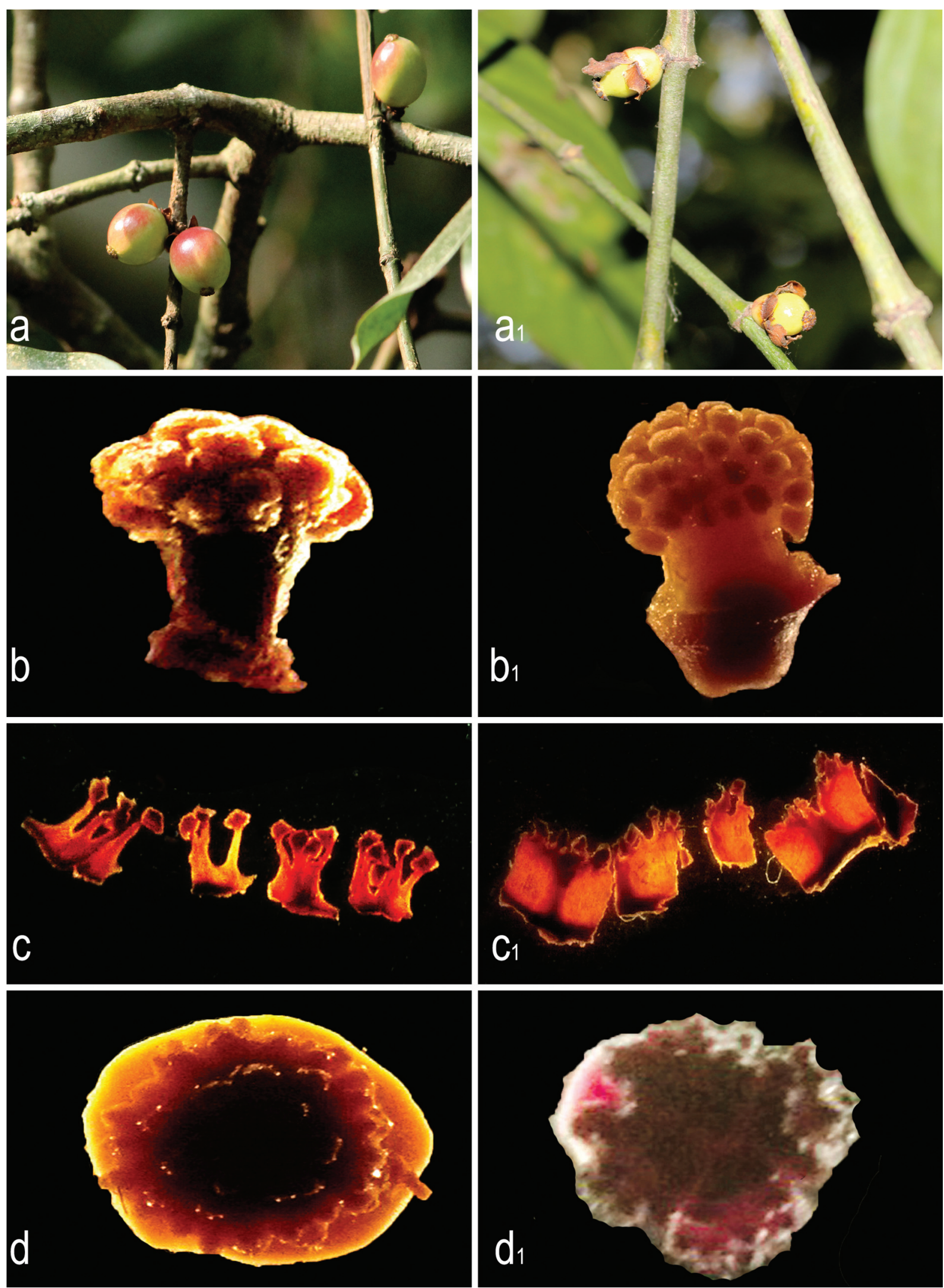

Fig. 2. Morphological differences between the two varieties of Garcinia cambogioides (Murray) Headland. a-d: G. cambogioides (Murray) Headland var. cambogioides. a. Fruits; b. Staminal mass; c. Staminodes; d. Stigma (cross section). a1-d1: G. cambogioides var. pictoria (Roxb.) P.S.Shameer \& N.Mohanan. a1. Immature fruits; b1. Staminal mass; c1. Staminodes; d1. Stigma (cross section) (photos by P.S. Shameer). 


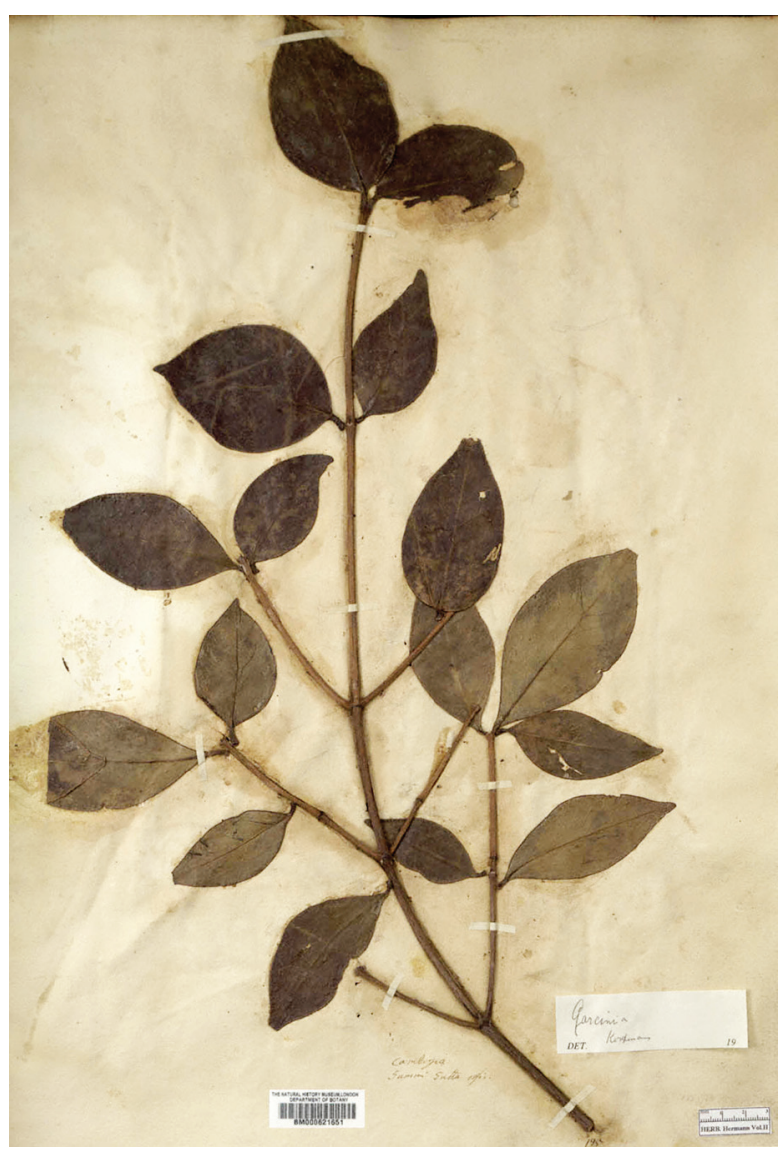

Fig. 3. Lectotype of Garcinia cambogioides (Murray) Headland (BM000621661) (C) The Natural History Museum (BM). Reproduced with permission.

V.A. Vasantha 1040 (CALI); Horanadu R.F., near Jain temple area, 27.02.1984, E. Vajravelu 77872 (MH); Shimoga district, Agumbe, 850 m, 28.11.1983, M.S. Francis 1040 (CALI); ibid., K. Shanthi 1041 (CALI). Kerala, Kollam district, Kulathupuzha (Colaturpolay), 23.01.1896, T.F. Bourdillon 734 (FRC); Kulathupuzha, Arippa, 150 m, 03.08.1981, N. Sasidharan 1470 (KFRI); Naduvannorkadavu near Choodal bridge, 02.06.1964, K.N. Subramanian 1548 (FRC); Malappuram district, Thalichola, 10.04.1982, Philip Mathew 28439 (CALI); Karuvarakundu, 16.06.1982, Philip Mathew 33368 (CALI); Nilambur, Nadukani, 525 m, 14.02.1985, N. Sasidharan 3342 (KFRI); Palakkad district, way to Silent Valley Dam, 28.06.1976, P. Bhargavan 47238 (MH); Mukkali forest, 05.11.1976, E. Vajravelu 48852 (MH); Silent Valley, R.F. above Dam site 09.04.1978, N.C. Nair 56703 (MH); Way to Aruvampara Estate, 24.04.1980, V.J. Nair 67281
(MH); Dam site to Valiyaparathode, 05.12.1980, N.C. Nair 69118 (MH); Attappady, Manthampotti, +500 m, 15.11.1985, N. Sasidharan 3615 (KFRI); Silent Valley National Park, MPCA, 08.03.2003, C. Kunhikannan \& N. Venkatasubramanian 14833 (FRC); Silent Valley, Wallakkadavu, 02.02.1994, Jomy Augustine 13193 (KFRI); ibid., 18.11.2014, P.S. Shameer 79660 (TBGT); ibid., 16.12.2014, P.S. Shameer 79665 (TBGT); Thirussur district, Chalakkudy, Palapitty range, 24.02.1982, K.N. Subramanian 7974 (FRC); Chalakkudy, Kodakkalthodu, Palapitty range, 24.02.1982, K.N. Subramanian 7989 (FRC); Peechi, Vengappara, +425 m, 19.12.1988, N. Sasidharan 5045 (KFRI); Thiruvananthapuram district, Bonacord, 29.05.1989, N. Mohanan 8416 (TBGT); Attayar, 02.03.1991, N. Mohanan 10564 (TBGT); Chemmunjii Hills, 22.01.2014, P.S. Shameer 79610 (TBGT); Wayanad district, Kambamala, Begur Range, 06.05.1983, N. Venkatasubramanian 9370 (FRC). Tamil Nadu, Coimbatore district, Iyyerpadi, 20.02.1901, C.A. Barber 3831 (MH); Anamalais, 28.10.1901, C.A. Barber $3874(\mathrm{MH})$; Udumanparai, Anamalais, 03.05.1903, C.A. Barber 5760 (MH); Thirunelveli district., Kannikatty, 19.03.1917, s.coll. 14653 (MH). SRI LANKA, s.loc., s.d., s.coll. 60488 (MH); s.loc., March 1883, s.coll. 60489 (MH).

Typification: Murray (1789), Gaertner (1790), Desrousseaux (1792), Graham (1836), Wight (1839) and Headland (1856) did not cite any specimens. Maheshwari (1964) cited 'Type: Hermann, Ceylon (BM)'. Headland (1856) also mentioned the name of Hermann, and that the plant was first made known from Ceylon by him in 1670. On perusal of BM collections we found two specimens of Hermann 195 (BM000621661 and BM00621719 digital images!) and could not determine which among the two is mentioned by Maheshwari as the type. As per Art. 9.17 of the nomenclature code (Turland et al., 2018), Maheshwari's typification could be considered as first-step lectotypication and need narrowing down to a single one of these specimens by subsequent lectotypification. Hence we designate Hermann 195 (BM000621661) as lectotype (second-step), for Garcinia cambogioides 
and the other (BM00621719) consequently as isolectotype.

Garcinia cambogioides (Murray) Headland var. pictoria (Roxb.) P.S.Shameer \& N.Mohanan, comb. nov.

Fig. 4

Garcinia pictoria Roxb., Fl. Ind. 2: 627.1832; Wight, Icon. Pl. Ind. Orient. 1(6-8): t. 102. 1839; Choisy, Mem. Soc. Phys. Geneve 12: 417. 1851; Headland, Man. Mater. Med. Therap., ed. 3: 340, f. 49. 1856; Planch. \& Triana, Ann. Sci. Nat. Bot. ser. 4, 14: 355. 1860; Drury, Indian Fl. 1: 141. 1864; Bedd., Fl. Sylv. S. India 7-14: tt. 86-87. 1871; Pierre, Fl. Forest. Cochinch. 32: t. 85B. 1883; Vesque in A.DC., Monogr. Phan. 8: 476. 1893; Gamble, Man. Ind. Timb. 55. 1902; Brandis, Indian Trees 53. 1906; Sealy, Kew Bull. 11(2): 341. 1956; Mabb., Taxon 26(5-6): 529. 1977. Hebradendron pictorium

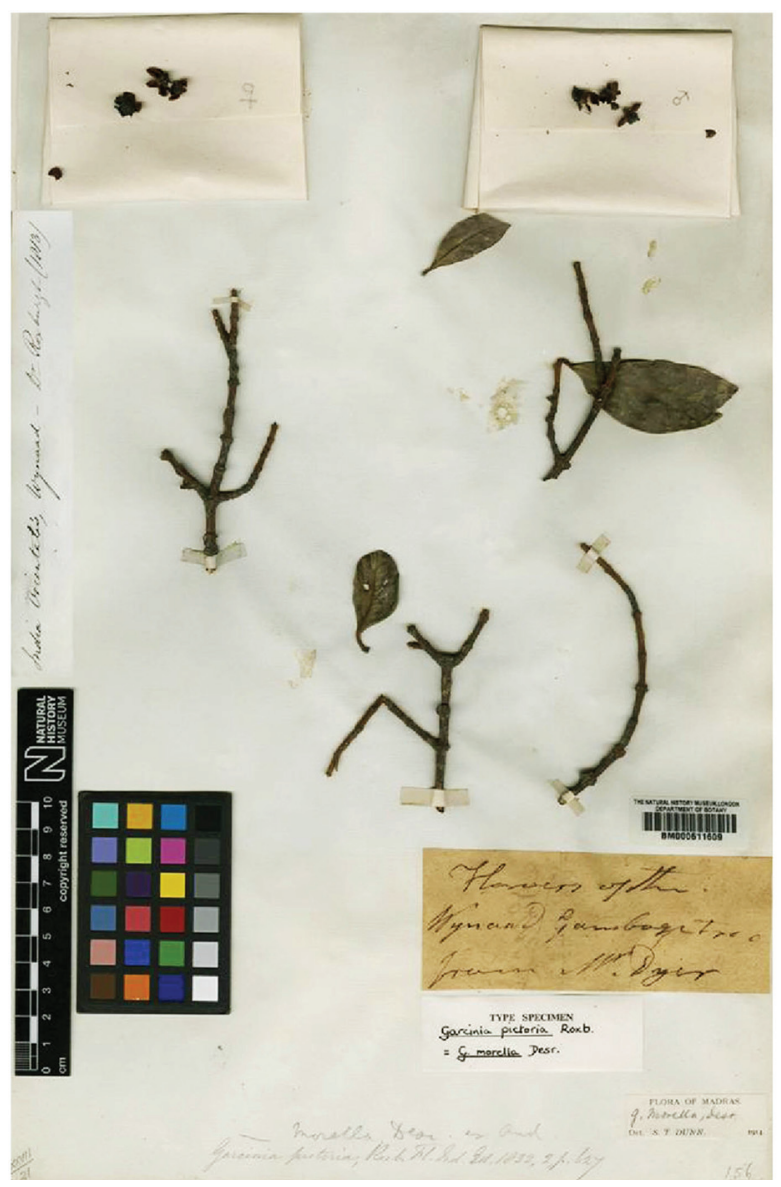

Fig. 4. Holotype of Garcinia cambogioides var. pictoria (Roxb.) P.S.Shameer \& N.Mohanan (BM000611609) (C) The Natural History Museum (BM). Reproduced with permission.
(Roxb.) Royle, Man. Mater. Med. 305. 1847. Type: INDIA, Kerala, Wayanad, s.d., Samuel Dyer s.n. (holo BM [BM000611609 digital image!]).

Evergreen trees, up to $20 \mathrm{~m}$ tall, with conical crown. Leaves elliptic-ovate, $8-10 \times 3-5 \mathrm{~cm}$, acute or attenuate at base, entire at margins, acute at apex. lateral veins conspicuous, c. 20 pairs on either side of midrib. Male flowers axillary, solitary. Female flowers axillary. Fruits oblongoid or subglobose, 3-5 $\times 1.5-2 \mathrm{~cm}$, smooth, reddish when ripe, crowned by 4-lobed, confluent verrucose, tubercled stigma. Seeds oblong-reniform.

Flowering \& fruiting: Flowering from November to December; fruiting from May to June.

Habitat: In evergreen forests, above $900 \mathrm{~m}$; on stream side.

Distribution: Endemic to southern Western Ghats.

Specimens examined: INDIA, Karnataka, Uttara Kannada district (North Kanara), 02.01.1892, s.coll. 2662 (CAL). Kerala, Wayanad district, Puthoorvayal, Manikunnu Mala, 25.07.2012, P.S. Shameer 86640 (TBGT); Kuruva Island, 20.11.2014, P.S. Shameer 79656, 79657 (TBGT).

Typification: Roxburgh while describing G. pictoria (1832) acknowledged the help of Samuel Dyer, a surgeon at Tellicherry (in Kannur district of Kerala), who had collected the specimen and provided it for study. Maheshwari (1964) mentioned 'Type locality: Wynaad, Western Ghats (ex Roxb.)' but no specimen was cited. We could locate one relevant specimen at BM, collected from Waynad by Samuel Dyer (BM000611609 digital image!). Since this is the only specimen available, this could probably be the holotype.

\section{Acknowledgements}

Authors are thankful to the Kerala Forest Department for financial support and assistance in the field and University of Kerala for providing financial support as fellowship for Ph.D. Scholars. Thanks are due to Dr. K.N. Gandhi (Harward University) and Dr. Subir Bandhopadya (CAL), 
nomenclatural experts for their valuable advises in nomenclature. We thank the Director, JNTBGRI, for constant encouragements and facilities provided and the curators of Herbaria BM, CAL, K, KFRI, $\mathrm{MH}$ and TBGT for providing permission for access to their collections.

\section{Literature Cited}

ANDERSON T. 1874. Guttiferae. In: HOOKER J.D. (ed.), The flora of British India. Volume 1. L. Reeve \& Co., London. pp. 259-278.

ARISDASON W. \& P. DANIEL 2005. Guttiferae (Clusiaceae). In: DANIEL P. (ed.), The Flora of Kerala. Volume 1. Ranunculaceae - Connaraceae. Botanical Survey of India, Kolkata. pp. 328-353.

CHOISY J.D. 1851. Description des Guttiferes de I'Inde. Mémoires de la Société de Physique etd' Histoire Naturelle de Geneve 12: 381-440.

DASSANAYAKE M.D. \& F.R. FOSBERG 1980. A revised handbook to the flora of Ceylon, Volume 1. Oxford \& IBH Publishing Company, New Delhi.

DESROUSSEAUX L.A.J. 1792. In: LAMARCK J. (ed.), Encyclopédie Méthodique, Botanique. Volume 3. Panckoucke, Paris. p. 701, t. 405, f. 2.

DUNN S.T. 1915. Guttiferae. In: GAMBLE J.S. (ed.), Flora of the Presidency of Madras. Volume 1. Adlard \& Sons Ltd., London. pp. 71-77.

GAERTNER J. 1790. De Fructibus et Seminibus Plantarum. Volume 2. G.H. Schramm, Tubingen.

GRAHAM R. 1836. Remarks on the gamboge tree of Ceylon, and the character of Hebradendron, a new genus of Guttiferae, and that to which the tree belongs. Companion to the Botanical Magazine 2(19): 193-200.

HEADLAND F.W. 1856. Medicinal plants, from Ranunculaceae to fungi. In: ROYLE J.F. (ed.), A manual of materia medica and therapeutics. Third edition. J. Churchill, London. pp. 266-698.

MAHESHWARI J.K. 1964. Taxonomic study of Indian Guttiferae III. The genus Garcinia L. s.l. Bulletin of the Botanical Survey of India 6: 107-135.

MURRAY A.J. 1789. Commentatio de arboribus gummi- guttae fundentibus. Commentationes Societatis Regiae Scientiarum Gottingensis. Gottingae 9: 169-184.

PLANCHON, J.É. \& J.J. TRIANA 1860 Mémoire sur la famille des Guttiferes. Annales des Sciences Naturelles (Botany), Series 14: 226-367.

ROGERS Z.S. \& P.W. SWEENEY 2007. Two distinctive new species of Malagasy Garcinia (Clusiaceae). Systematic Botany 32: 772-779. https://doi.org/10.1043/07-22.1

ROXBURGH W. 1832. Flora Indica, or descriptions of Indian plants. W. Thacker \& Co., Kolkata.

SALDANHA, C.J. \& D.H. NICOLSON 1976. Flora of Hassan District, Karnataka, India. Amerind Publishers, New Delhi.

SHAMEER P.S., RAMESHKUMAR K.B. \& N. MOHANAN 2016. Diversity of Garcinia species in the Western Ghats. In: RAMESHKUMAR K.B. (eds.), Diversity of Garcinia species in the Western Ghats: phytochemical perspective. Jawaharlal Nehru Tropical Botanic Garden and Research Institute, Thiruvananthapuram. pp. 1-18.

SHAMEER P.S., SABU T. \& N. MOHANAN 2017. Garcinia gamblei, a new species from the southern Western Ghats, India. Phytotaxa 297(1): 71-76. https:// doi.org/10.11646/phytotaxa.297.1.7

SINGH N.P. 1993. Clusiaceae (Guttiferae nom. alt.) In: SHARMA B.D. \& N.P. BALAKRISHNAN (eds.), Flora of India. Volume 3. Botanical Survey of India, Kolkata. pp. 86-151.

TURLAND N.J., WIERSEMA J.H., BARRIE F.R., GREUTER W., HAWKSWORTH D.L., HERENDEEN P.S., KNAPP S., KUSBER W.H., LI D.Z., MARHOLD K., MAY T.W., MCNEILL J., MONRO A.M., PRADO J., PRICE M.J. \& G.F. SMITH (eds.) 2018. International Code of Nomenclature for algae, fungi, and plants (Shenzhen Code) adopted by the Nineteenth International Botanical Congress Shenzhen, China, July 2017. Regnum Vegetabile 159. Koeltz Botanical Books, Glashütten. https://doi.org/10.12705/ Code. 2018.

VESQUE J. 1893. Guttiferae. In: CANDOLLE C.DE (ed.), Monographiae Phanerogamarum. Volume 8. Sumptibus G. Masson, Paris. pp. 1-669.

WIGHT R. 1839. Icones Plantarum Indiae Orientalis. Volume 1(6). J.B. Pharoah, Madras. 